DOI 10.37882/2223-2982.2021.08.08

\title{
МОТИВ БОРЬБЫ С «СИОНИЗМОМ» Н.И. КОНДРАТЕНКО: ИСТОЧНИКИ, ПРОИСХОЖДЕНИЕ И РЕКОНСТРУКЦИЯ
}

\section{THE MOTIVE OF THE FIGHT AGAINST "ZIONISM" N.I. KONDRATENKO: SOURCES, ORIGIN AND RECONSTRUCTION}

\section{K. Gusev}

Summary: The article deals with the problematic issue of the origin of the motive of the "fight against Zionism" in public speeches of N.I. Kondratenko. The author reveals a complex of objective and subjective factors that determined the genesis of this phenomenon - historical premises in the Kuban and in the country, general civil and personal identity crises, the need for a publicly available explanation of the collapse of the USSR, as well as the critical state of Russia in the 1990s. The system of views of N.I. Kondratenko on the issue of the "Zionist threat" is reconstructed, its theoretical sources and actors of ideological support are revealed. A special historical model formed by the politician is reproduced, based on the actualization of the problems of the present and their translation into the past. The assessment of the "anti-Zionist" narrative of N.I. Kondratenko is carried out within the framework of the methodological concept of the conspiracy theory.

Keywords: N.I. Kondratenko, Zionism, identity crisis, Kuban, conspiracy theory, conspiracy theories.
$\mathrm{T}$ ема «борьбы с сионизмом», наравне с проблемой «цен на энергоносители», является превалирующей в устном и письменном наследии Н.И. Кондратенко. Та настойчивость и последовательность, с которой политик говорил об «угрозе сионизма» на протяжении более двадцати лет, свидетельствует об убежденности Н.И. Кондратенко в правдивости транслируемых им идей. С целью понимания природы данного убеждения в статье предлагается решение нескольких исследовательских задач. Во-первых, необходимо выявить объективные и субъективные причины популярности «антисионистской» риторики на Кубани и в России в 1990-е годы. Вовторых, определить внутренние и внешние источники, повлиявшие на генезис мотива «борьбы с сионизмом» у Н.И. Кондратенко. В-третьих, реконструировать исторические взгляды политика в контексте данной проблемы, а также дать им научно-методологическую оценку.

Определим исторические корни и предпосылки «борьбы с сионизмом» на Кубани и в России. Доктор исторических наук С.С. Минц выявляет особенности региона и страны в целом, обусловленные «известной долей традиционализма в российской жизни, высокой организующей ролью государства и большой зависимо-
Гусев Константин Дмитриевич

Аспирант, ФГБОУ ВО «Кубанский государственный университет», г. Краснодар gusev-konstantin-2013@mail.ru

Аннотация: В статье рассматривается проблемный вопрос происхождения мотива «борьбы с сионизмом» в публичных выступлениях Н.И. Кондратенко. Выявляется комплекс объективных и субъективных факторов, обусловивших генезис данного феномена - исторические предпосылки на Кубани и в стране, общегражданский и личностный кризисы идентичности, необходимость общедоступного объяснения произошедшего краха СССР, а также критического состояния России в 1990-е гг. Реконструируется система взглядов Н.И. Кондратенко по вопросу «сионистской угрозы», выявляются его теоретические источники и акторы идейной подпитки. Воспроизводится сформированная политиком особая историческая модель, основанная на актуализации проблем настоящего и их трансляции в прошлое. Осуществляется оценка «антисионистского» нарратива Н.И. Кондратенко в рамках методологического концепта теории заговора.

Ключевые слова: Н.И. Кондратенко, сионизм, кризис идентичности, Кубань, теория заговора, конспирология.

стью новоприсоединенного региона от состояния российской государственности» [8, с. 176]. Так, со времен Екатерины II царская администрация не приветствовала появление евреев на Кубани, однако целенаправленная борьба с ними началась участниками Белого движения в годы Гражданской войны [8, с. 169]. Российская империя являлась государством с самым большим еврейским населением в мире, однако существование различных ограничений («черты оседлости», погромов) привело к широкой эмиграции евреев из страны. В советское время обвинения в симпатиях к сионизму являлись «нормой в конкурентной борьбе государственных служащих» [8, с. 169]. Причем это явление было распространено среди интеллектуальной элиты - деятелей науки, культуры и искусства [8, с. 169]. Начиная с послевоенного периода «пика сталинизма», в СССР существовала практика государственного антисемитизма («дело врачей», наличие «5-й графы»), при этом получил распространение феномен бытового антисемитизма. Подъем национального сознания в результате победы в Шестидневной войне привел к репатриации 100 тыс. евреев из СССР в первой половине 1970-х годов. Массовый выезд евреев за пределы страны продолжился в период Перестройки и в 1990-е годы - численность диаспоры в России сокра- 
тилась более чем на 60\%. Однако именно в 1990-е годы антисемитизм стал традицией публичной политики в стране, поскольку многочисленные политические дебаты замыкались на вопросе «еврейского происхождения» олигархов. Создание «образа врага» в данном случае опиралось на распространенные в обществе стереотипы и предрассудки [15, с. 13].

Обострение «борьбы с сионизмом» в 1990-е годы объясняется кризисом национальной и гражданской идентичности [14], который был вызван распадом Советского Союза [8, с. 176]. Данный кризис имел глубинный и многофазовый характер, проявившись в «неспособности государственных структур разных уровней защитить интересы собственных граждан» [8, с. 176]. При этом в конце 1980-х годов Н.И. Кондратенко испытал еще и личный кризис идентичности, наложившийся на общий кризис номенклатурного коммунистического сознания [5]. В условиях двойного кризиса Н.И. Кондратенко переформатировал идейные взгляды на прошлое и настоящее страны, трактуя крушение СССР, как итог «происков мировой закулисы». Как отмечает С.Е. Шишкова-Шипунова, Н.И. Кондратенко «за это зацепился, как бы найдя для себя объяснение всему происходящему» [4]. Отметим, что Н.И. Кондратенко являлся весьма образованным и эрудированным человеком, но у него отсутствовало системное гуманитарное образование. Это могло помешать политику критически отнестись к теории «сионистского заговора». С.Е. Шишкова-Шипунова утверждает: «Кондратенко не был гуманитарием и идеологом ни по образованию, ни по опыту работы, поэтому действовал на этом фронте довольно неуклюже» [4]. Однако аспект гуманитарной образованности не играл здесь определяющей роли. Так, перестроечный «кризис идентичности» коснулся и интеллектуальной элиты российского общества - писателей. В «Письме 74-х» многие знаковые литераторы эпохи подписались под «антисионистскими тезисами» в 1991 году. Впоследствии Н.И. Кондратенко неоднократно ссылался на них: «Цвет русской нации, писатели, художники - Распутин, Бондарев, Белов, Знаменский и другие - криком кричат о сионизме, призывая к бдительности» [7, с. 11]. Как отмечает И.А. Яблоков, именно представители элит обладают интеллектуальными способностями, которые позволяют делать свои взгляды для окружающих достаточно убедительными [15, с. 13]. Таким образом, на Кубани и в целом в России существовали исторические предпосылки для всплеска «борьбы с сионизмом» в 1990-е годы. Они были реализованы из-за крушения СССР, который вызвал кризис гражданской идентичности среди местных жителей и личный кризис у Н.И. Кондратенко, а также выявил необходимость логического объяснения произошедшей со страной катастрофы.

Взгляды Н.И. Кондратенко по вопросу «сионистской угрозы» характеризуются автором в рамках теории заго- вора. Научным определением данного понятия является особый способ восприятия действительности, при котором отдельные события или окружающий мир находятся в неразрывной связи с действиями определенных скрытых сил (группы людей), которые их контролируют [15, c. 12]. На деле теория заговора оказывается упрощением познания окружающего мира, позволяющая объяснить человеку сложные и многоуровневые процессы, зачастую не поддающиеся анализу без серьезных знаний и теоретической подготовки. Для Н.И. Кондратенко точкой бифуркации, заставившей политика искать ответы на проблемные вопросы, стало непонимание причин скоропалительного краха Советского Союза. Характерной чертой теории заговора остается доступное объяснение широким массам кризисного положения сообщества, что создает для людей психологический комфорт в восприятии действительности, перенося ответственность за изменения на «других» [15, с. 12].

Выявим у Н.И. Кондратенко источники формирования устойчивого «антисионистского» дискурса. Помимо указанных писателей и их публикаций, в конце 1980-х годов в литературно-художественном альманахе «Кубань» регулярно появлялись работы о заговоре «мировой закулисы» против СССР, которые политик мог изучить. В.П. Громов считает, что в конце 1980-х годов Н.И. Кондратенко обнаружил текст «Протоколов сионских мудрецов» (подложный антисемитский документ), ставший источником для вдохновения «антисионистской» идеи [3]. Сам Н.И. Кондратенко в выступлениях ссылался на «Катехизис сионистов» («Катехизис еврея в СССР») еще один фальсифицированный источник [6]. Без детализации политик утверждал, что о сионизме «написаны тома», «тысячи книг во всех странах» [7, с. 75, 208]. Однако, делая эту символическую ссылку, Н.И. Кондратенко обычно не приводил названий работ и фамилий их авторов. Политик регулярно повторял о принятой в 1975 году резолюции $3379 \mathrm{OOH}$, осуждавшей сионизм, как «форму расизма и расовой дискриминации» [7, с. 15]. Данный документ был утвержден при активном участии СССР в специфических условиях «Холодной войны» и отменен по ее завершении в 1991 году. Н.И. Кондратенко ссылался на работы Дугласа Рида - английского журналиста-ревизиониста, отрицавшего уничтожение Гитлером евреев [7, с. 10; 11]. Также политик обращался к воспоминаниям А. Симановича, традиционно критикуемые в профессиональной научной среде [7, с. 113; 12]. В целом Н.И. Кондратенко в качестве источника для формирования мотива «сионистской угрозы» опирался на сомнительную литературу, появившуюся на волне «гласности» и популярную в 1990-х годах.

Возможно, что «антисионистская» идея была привита Н.И. Кондратенко его окружением. С.Е. Шишкова-Шипунова утверждает, что на политика мог повлиять член команды и ее идеолог Н.И. Харченко [13, с. 123-124]. В 
статье «Клин клином вышибает» он не только воспроизвел идеи, озвучиваемые Н.И. Кондратенко, но и попытался подвести теоретическую основу под данную концепцию [7, с. 3-7]. Н.И. Харченко ссылался на работы таких публицистов, как А. Ильин, Д. Рид, А. Романенко, Г. Климов, М. Назаров, В. Бушин, Б. Миронов, А. Крутов [7, с. 4]. Перечисленные авторы являются сторонниками теории заговора. Также Н.И. Харченко формулирует тезисы, которыми активно пользовался Н.И. Кондратенко: о сионизме, как о «коварном» политическом (но не национальном) течении; о «человеконенавистнической идеологии», претендующей на «мировое господство»; о стремлении к порабощению стран и народов через «экономическое разорение и нравственное растление» [7, с. 4-5]. Идеолог называл борьбу с сионократией «без всяких натяжек... основным вопросом русской и мировой истории» [7, с. 7]. Данные идеи в скорректированном виде многократно воспроизводились Н.И. Кондратенко. Есть вероятность, что частично они были усвоены именно от Н.И. Харченко.

Н.Г. Денисов, еще один член команды Н.И. Кондратенко, пытался теоретически систематизировать собственные взгляды по «сионистскому» вопросу. В программной брошюре «Идеология созидательного сопротивления на пороге XXI века» он ссылается на «Протоколы сионских мудрецов», «Катехизис еврея в СССР», пишет о существовании мирового надгосударственного правительства, которое через несколько уровней контроля захватывает различные государства, в т.ч. Россию [2, с. 8-10]. Как отмечает С.Е. Шишкова-Шипунова, «соратники... подталкивали и разжигали, подсовывая ему соответствующие публикации, которых тогда выходило довольно много» [4]. Однако и сам Н.Г. Денисов мог прийти к этим идеям под влиянием Н.И. Кондратенко. Стоит отметить, что многие люди из окружения политика в той или иной степени стали разделять взгляды Батьки на существование всемирного заговора [9]. Таким образом, выявленный «антисионистский» элемент в среде окружения политика мог оказать влияние на формирование (или по крайней мере сохранение) у Н.И. Кондратенко устойчивой идеи «происков мировой закулисы». В целом могла иметь место как идейная подпитка Н.И. Кондратенко, так и его обратное влияние на свое окружение.

Таким образом, вплоть до собственной кончины Н.И. Кондратенко оставался твердо убежден в реальности «сионистской угрозы» в силу ряда объективных и субъективных причин: из-за общегражданского кризиса идентичности времен Перестройки, личного кризиса идентичности, наличия исторической антисемитской традиции в обществе, недостатка системного гуманитарного образования у политика, подпитки со стороны окружения, желания логически объяснить самому себе и окружающим крах СССР.
Реконструируем и проанализируем взгляды Н.И. Кондратенко, которые он регулярно озвучивал в контексте «антисионистского» нарратива. Отметим, что политик не писал фундаментальных теоретических работ по теме «сионизма», его идеи известны в первую очередь из опубликованных речей. В целом конспирологические воззрения «имеют широкое хождение именно на уровне слуховой культуры» [15, с. 13].

Широкую огласку «антисионистские тезисы» Н.И. Кондратенко получили 26 апреля 1991 года, когда политик выступил на сессии краевого Совета народных депутатов с резонансным докладом «Дойти до разума и сердца каждого» [7, с. 8-15]. Эта речь стала программной - на протяжении дальнейшей политической карьеры Н.И. Кондратенко незначительно корректировал и развивал обозначенные здесь идеи. Выступление транслировалось в прямом эфире по краевому телевидению и радио, затем было опубликовано в краевой печати, вызвав широкую реакцию внутри кубанского общества. Говоря о задачах доклада, Н.И. Кондратенко впоследствии замечал, что хотел «открыть людям глаза» на сионистскую угрозу, «понимал, что замалчивать это - значит предать» [7, с. 32]. Так, в рамках теории заговора существует традиционное мифологическое деление на «своих» и «чужих», что ведет к формированию образа врага.

Глубоко продуманная политика сионизма, по Н.И. Кондратенко, «вырисовывается как международный заговор против России и, прежде всего, - против русской нации». [7, с. 29]. Типичной чертой теории заговора является наличие тайной организации, цель которой - распространение власти над миром, создание «антисистемы» в отношении традиционного миропорядка [1, с. 12]. Целью сионистов, по Н.И. Кондратенко, был развал страны, уничтожение народов, а затем - мировое господство [7, с. 13, 142]. Политик крайне высоко оценивал степень «сионистской опасности» - «этой реальной угрозы для судеб русского народа» [7, с. 10-11]. Также для теории заговора характерна аномалия ее участников - они обладают существенно большими возможностями, нежели «рядовой человек» [1, с. 12]. Н.И. Кондратенко утверждал, что враги «хорошо организованы, быстро перегруппировываются», маскируются под различные политические силы, не определяя их конкретных имен [7, с. 13]. Фактором кризиса 1990-х годов Н.И. Кондратенко называл внутреннее предательство, в частности - русской интеллигенции. Из-за этого отношение Батьки к интеллигенции выглядит довольно противоречиво: «Она может и предавать, но и спасти нашу страну без интеллигенции тоже невозможно». [7, с. 40]. Политик подчеркивал: «Сионистом может быть и русский, предавший национальные интересы» [7, с. 124].

Классической модели теории заговора сопутствует усложнение ее доказательства через включение разно- 
образных факторов [15, с. 12]. Например, Н.И. Кондратенко принципиально разводил «сионизм», как политическое течение, и еврейский народ, «это то же самое, что немец - нация, фашизм - политика» [7, с. 11]. Батька подчеркивал, что он - интернационалист, но сионизм - это политика, причем «злая, хитрая, коварная, жестокая и опасная», «мерзкое человеконенавистническое течение» [7, с. 11, 15, 203]. Н.И. Кондратенко часто повторял: «Конечно, грешно каждого еврея обвинять в сионизме, но трижды грешно русским не видеть политику сионизма в своей стране» [7, с. 142]. Политик подчеркивал, что среди его друзей много евреев [7, с. 140]. При этом часть людей, слушавших речи Н.И. Кондратенко, воспринимала их с антисемитским акцентом. Сам Батька использовал такую характеристику как «жидовье» [13, с. 123]. Во второй половине 1990-х годов центральная пресса для борьбы с оппозиционным политиком стала использовать его «антисионистские» взгляды, чтобы приклеить ярлык «антисемита» и создать репутацию «оголтелого ксенофоба». Но, как отмечает С.Е. ШишковаШипунова, «Он плевать хотел на „имиджевые проблемы“. Чем больше его ругали в федеральных СМИ, тем больше он укреплялся в своей правоте» [4].

Выявленный идейный эклектизм и внутренние противоречия взглядов Н. И. Кондратенко свидетельствуют об их конспирологическом характере.

В качестве способа достижения общественного признания авторы теории заговора часто используют огромный реферативный и фактологический материал, придавая ему вид научного знания [15, с. 12]. Это позволяет связывать реальность и вымысел, верифицируя теорию в глазах окружающих [15, с. 12]. Для борьбы с «сионистским закабалением» Н.И. Кондратенко активно обращался к позитивному патриотическому опыту прошлого России, регулярно ссылаясь на такие объединяющие фигуры, как Сергий Радонежский, Александр Невский, Дмитрий Донской, А.В. Суворов, М.И. Кутузов, Г.К. Жуков, К. Минин и Д. Пожарский (памятник последним использовался на эмблеме народно-патриотического движения «Отечество» (Кондратенко)) [7, с. 83-84, 96]. Политик опирался на интегрирующие события прошлого, в которых ключевую роль, по его мнению, сыграли «люди труда» - битва на Чудском озере, Куликовская битва, снятие татаро-монгольского ига, партизанский опыт Отечественной войны 1812 года, Великая Отечественная война 1941-1945 гг. [7, с. 83-84, 87].

Специфический тип историзма является неотъемлемой чертой теории заговора [15, с. 14]. Прошлое в данном случае видится и трактуется сквозь призму проблем настоящего, а сконструированная матрица исторического развития наполняется разнообразными фактами, фиктивно подтверждающими правдивость заговора [15, с. 15]. Так Н.И. Кондратенко конструировал оригиналь- ную концепцию истории России XX века, главным сюжетом которой являлась борьба русского народа с «сионизмом». Согласно Н.И. Кондратенко, «сионизм» появился в 1897 году и начал вести активную борьбу против России, завладев ею в 1917 году и во время Гражданской войны: «Революционеры из-за границы к нам приехали в кожанках, нацепив парабеллумы, и, окрасив нас, русских, в красных и белых, заставили стреляться, то был сионизм» [7, с. 32]. Политик часто подчеркивал национальный состав революционеров: «... почему это среди эмиссаров революции, прибывших в начале века в Россию в опломбированных вагонах, не было русских?» [7, с. 112]. «Сионисты», по Н.И. Кондратенко, являлись существенной частью большевиков: «Да, была и есть партия, но были и троцкие, и свердловы, каменевы, зиновьевы, все до одного поменявшие фамилии» [7, с. 14]. Политик отмечал, что «большевизм был замешан на крутом сионизме» [7, с. 77]. Зачастую создатели теории заговора используют образы врага, актуализируя негативный исторический опыт; они апеллируют не к сознанию, а к эмоциям и негативным объектам массового сознания [15, с. 13]. Так сообщество мобилизуется против определенной группы людей, с которой связываются текущие неудачи [15, c. 13].

Ключевым антигероем революционных событий для Н.И. Кондратенко являлся Л.Д. Троцкий: «Это он - жидомасон Бронштейн - составлял для большевиков генеральный план революционного обновления мира» [7, с. 114]. Также политик крайне негативно оценивал роль личности Я.М. Свердлова: «Зловещая фигура для России и особенно для казаков, соратник Троцкого... ставил задачу расколоть деревню, разжечь там такую же гражданскую войну, как и в городах» [7, с. 115]. По мнению Н.И. Кондратенко, большую роль в процессе «закабаления» русских сыграл Бунд - «еврейская фракция в Российской социал-демократической рабочей партии, сионистская по своей сути» [7, с. 32]. Политик подчеркивал, что В.И. Ленин состоял в Бунде, а затем резко порвал с ним, чем вызвал покушение Ф. Каплан. После смерти В.И. Ленина «сионисты» якобы поставили у власти «нацмена» И.В. Сталина [7, с. 33]. Подобным образом формируется особый тип конспирологического историзма, в рамках которого прошлое иллюзорно упорядочивается, но человек не может что-либо изменить, поскольку существует безграничная власть группы заговорщиков [15, с. 15].

Внутри конспирологической матрицы противоречия не замечаются, а, напротив, выстраиваются в формально-логическую модель. Н.И. Кондратенко утверждал, что он не сталинист, но в целом позитивно характеризовал личность И.В. Сталина - «не было у нас более русского руководителя, чем он», который не воровал, не копил, ничего не оставил после себя, не поменял сына на фельдмаршала [7, с. 33, 57, 122]. Главную заслугу вождя политик видел в успешной борьбе с «сионизмом», 
в том числе - в персональных репрессиях: «Если посмотрите "цепочку“... тухачевские, якиры, фельдманы, уборевичи... опять никого русских среди них. Дело врачей-вредителей — опять никого русских» [7, с. 33]. Однако, по Н.И. Кондратенко, И.В. Сталин не смог победить «сионистов» полностью - именно они виновны в преступлениях 1920-1930-х гг. По мнению политика, вся репрессивная машина, включая ГУЛАГ, контролировалась и управлялась «сионистами»: «среди начальников тюрем и лагерей в то время 95 процентов составляли представители сионократии» [7, с. 15]. Политик персонализировал роль враждебных сил в местной кубанской истории, говоря об их вине в расказачивании и голоде 1932-1933 гг. «Еврей-сионист» Л.М. Каганович называется Н.И. Кондратенко «организатором искусственного голода», который «оцеплял войсками кубанские станицы до полного вымирания жителей» [7, с. 15, 116]. У Н.И. Кондратенко даже возникла идея составить «Книгу Памяти» «жертв сионистского геноцида на Кубани», сформировав специальную комиссию, работу которой могла профинансировать Администрация Краснодарского края [7, с. 116117]. Согласно Н.И. Кондратенко, во II мировой войне СССР также противостоял «сионистам», вскормившим фашизм [7, с .94]. Политик утверждал, что после поражения в 1945 году «сионисты развернули» Третью мировую войну, цель которой - «переделить мир... обеспечить сытую жизнь „золотого миллиарда“ в новом тысячелетии» [7, с. 94]. Политическая карьера Н.И. Кондратенко началась в 1969 году в эпоху «брежневского застоя». Став губернатором, политик говорил, что уже в то время Политбюро и правительство было захвачено «сионистами» [7, с. 32-33]. Это якобы проявлялось в кадровой политике - на Н.И. Кондратенко «давили» с целью назначения им на различные должности «нерусских» [7, с. 32]. По утверждению политика, сам Л.И. Брежнев был «по корням - из них», а такие крупные структуры, как «Госплан, Госснаб были захвачены, пресса была сдана им» [7, с. 33]. М.С. Горбачев для Н.И. Кондратенко - «завербованный предатель», с приходом к власти которого «в стране разгорелся кадровый сионистский шабаш» [7, с. 34, 35, 205].
В 1989 году власть якобы перешла от КПСС к «бесформенному политическому конгломерату» [7, с. 14]. Путч ГКЧП политик называл «провокацией сионизма», сработавшей на Б.Н. Ельцина [7, с. 218-219]. Расстрел «Белого дома» в 1993 году также, по Н.И. Кондратенко, не прошел без участия отрядов «молодых еврейских боевиков» [7, с. 220]. Политик утверждал, что в 1990-е годы «сионисты» захватили национальное богатство России, запустив ряд процессов: «...все эти сатанинские механизмы разрушения запущены и действуют потому, что жизнью России и сегодня управляют нерусские» [7, с. 112, 122]. Сокращение населения России в 1990-е годы Н.И. Кондратенко называл «геноцидом» русского народа со стороны «сионистов» [7, с. 40]. Таким образом, транслируя в прошлое проблемы современности, формируется искаженный образ истории, основанный на многочисленных мифах и массовых стереотипах, что находит выражение в форме теории заговора.

Подводя итоги, отметим наличие системы факторов, обусловивших появление у Н.И. Кондратенко устойчивого мотива «борьбы с сионизмом», - общегражданский и личностный кризисы идентичности, вызванные развалом СССР; стремление логически объяснить данный крах и критическое состояние страны в 1990-е годы; влияние окружения и широкое распространение «антисионистской» литературы; исторические традиции отношений с евреями на Кубани и в России. Невозможность существенным образом изменить сложившуюся ситуацию обусловила особый тип конспирологического историзма, прочно усвоенного сторонниками Н.И. Кондратенко и им самим. Рассматривая прошлое в контексте проблем настоящего, политик создал формально-логическую модель истории страны, основанную на выборочных фактах и собственной трактовке. Выявленные источники происхождения и проведенная реконструкция системы взглядов Н.И. Кондратенко по вопросу «сионизма» позволили определить их в рамках теории заговора, которая на доступном языке объяснила ее автору и окружающим тяжелое положение в России, а также определила виновника данной ситуации.

\section{ЛИТЕРАТУРА}

1. Багдасарян В.Э. «Теория заговора» в отечественной историографии второй половины XIX-XX вв. М., 1999.

2. Денисов Н.Г. Идеология созидательного сопротивления на пороге XXI века. Краснодар, 2001.

3. Интервью автора с В.П. Громовым, Краснодар, 18 июня 2021 года.

4. Интервью автора с С.Е. Шишковой-Шипуновой, Краснодар, 17 июня 2021 года.

5. Интервью автора С С.С. Минц, Краснодар, 22 июня 2021 года.

6. Катехизис еврея в СССР // Великая Россия. URL: https://velikoross.org/forums/topic/katexizis-evreya-sssr (дата обращения: 26.06.2021).

7. Куда звал нас батько Кондрат. Майкоп, 2006.

8. Минц С.С. Борьба с «сионизмом» на Кубани // Социологический журнал. 2000. №.3-4. С.169-177.

9. Н.И. Кондратенко: след на земле // сост. Г.В. Мухина. Краснодар, 2015.

10. Протоколы сионских мудрецов // academic.ru.URL: https://news_enc.academic.ru/2535/\%22"Протоколы_сионских_мудрецов" (дата обращения: 
25.06.2021).

11. Рид Д. Спор о Сионе. М., 2018.

12. Симанович А.С. Распутин и евреи. Воспоминания личного секретаря Григория Распутина. М., 1991.

13. Шишкова-Шипунова С.Е. Десять правителей Кубани: от Медунова до Ткачева. Краснодар, 2015.

14. Эриксон Э. Идентичность: юность и кризис. М., 1996.

15. Яблоков И.А. Теория заговора и современное историческое сознание (на примере американской исторической мысли): автореф. дис. ... канд. ист. наук. Томск, 2010.

(c) Гусев Константин Дмитриевич (gusev-konstantin-2013@mail.ru).

Журнал «Современная наука: актуальные проблемы теории и практики»

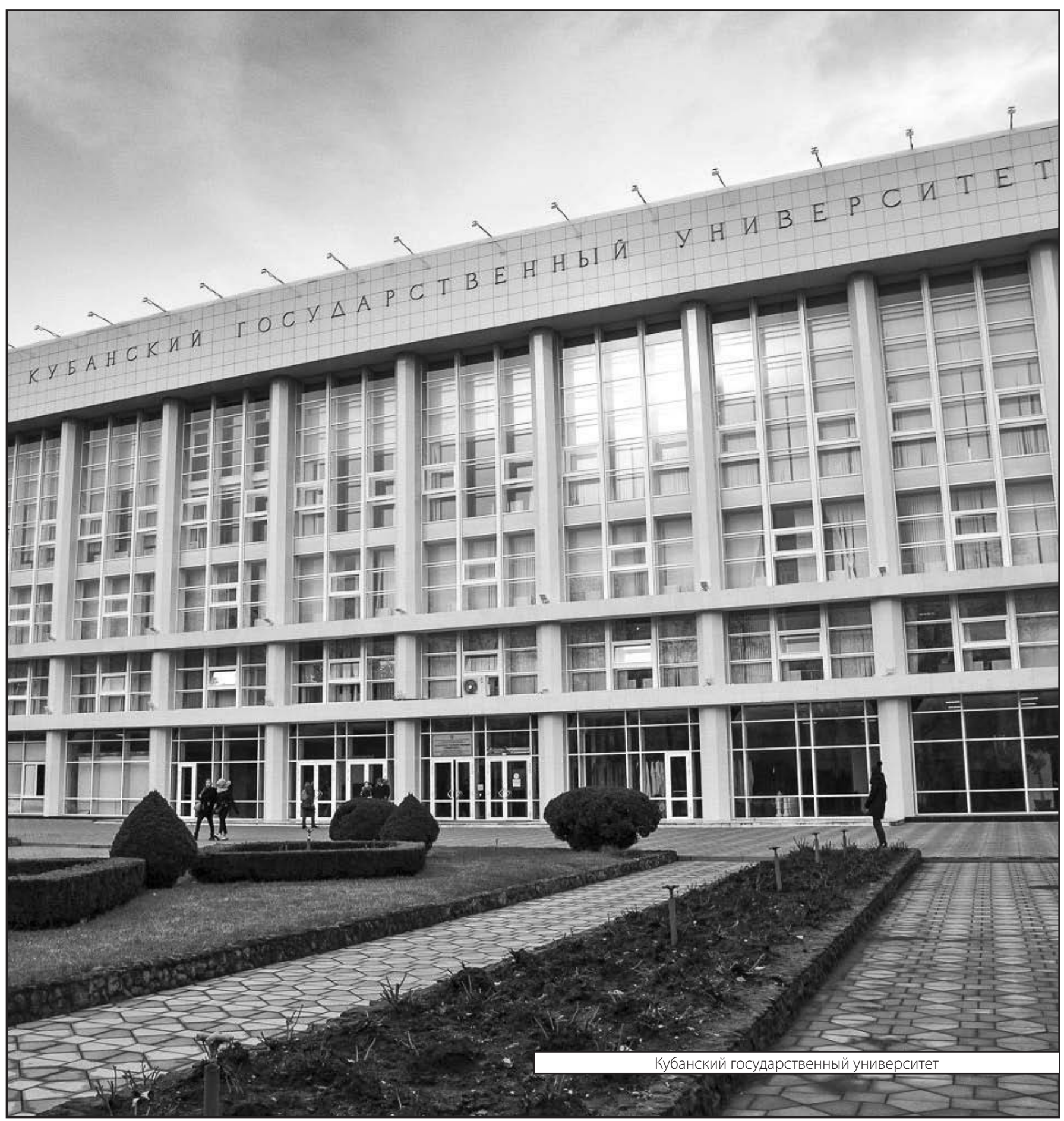

